\title{
Posterior scleral tuberculoma: case report
}

\author{
Tuberculoma escleral posterior: relato de caso
}

Antonio Augusto Velasco e Cruz ${ }^{1}$, Fernando Chahud $^{2}$, Rodrigo Feldman ${ }^{1}$, Patricia Mitiko Santello Akaishi ${ }^{1}$

\begin{abstract}
Posterior scleral tuberculoma formation is an extremely rare condition. The few reports on scleral involvement in tuberculosis refer to cases of anterior scleritis. In the present manuscript we describe a patient who had rheumatoid arthritis and developed a large posterior scleral tuberculoma. The lesion provoked retinal detachment and visual loss and was diagnosed only after enucleation due to a misdiagnosis of choroidal melanoma.
\end{abstract}

Keywords: Tuberculosis, ocular/diagnosis; Tuberculosis, ocular/immunology; Mycobacterium tuberculosis; Sclera/pathology; Melanoma; Tuberculoma; Immunosupressive agents; Human; Female; Aged; Case reports

\section{RESUMO}

A formação de granuloma tuberculoso na esclera posterior é um evento extremamente raro. Os poucos relatos de acometimento escleral na tuberculose referem-se a casos de esclerite anterior. No presente trabalho é descrito um caso de granuloma escleral posterior em um paciente portador de artrite reumatóide. A lesão provocou descolamento da retina e perda visual e só foi diagnosticada após enucleação por suspeita de melanoma de coróide.

Descritores: Tuberculose ocular/diagnóstico; Tuberculose ocular/imunologia; Mycobacterium tuberculosis; Esclera/patologia; Melanoma; Tuberculoma; Imunossupressores; Humano; Feminino; Idoso; Relatos de casos

\section{INTRODUCTION}

$\mathrm{T}$ uberculosis (TB) is an ancient illness that remains a global public health problem leading to approximately 1.6 million deaths each year ${ }^{(1)}$. The disease is caused by the Mycobacterium tuberculosis and in rare instances by other members of $M$. tuberculosis complex such as $M$. bovis, M. africanum and $M$. canetti(i). TB can affect any organ or tissue and is typically associated with granuloma formation. In the eye, large lesions (tuberculomas) are usually found only in the choroid ${ }^{(3)}$. In the present report we describe a large posterior scleral tuberculoma that was misdiagnosed as choroidal melanoma. At our best knowledge this is the first well documented case of posterior scleral tuberculosis granuloma.

\section{CASE REPORT}

A 66-year-old woman presented with a 3-month history of vision loss in the right eye. The patient was diabetic and had rheumatoid arthritis which had been treated for 8 years with desflazacort (5 mg/ day); naproxeno (500 mg/day) and leflunomide (20 mg/day). Purified protein derivative (PPD) test was negative and chest radiograph was normal. The visual acuity was no light perception in OD and 20/30 in OS. Examination of the left eye was unremarkable. In OD there was a dense cataract with $360^{\circ}$ posterior synechiae which precluded fundus view. B-scan ultrasonography demonstrated a

\footnotetext{
Study carried out at the Department of Ophthalmology, Otorhinolaringology and Head and Neck Surgery, Hospital das Clínicas of Ribeirão Preto - USP, Brazil.

${ }^{1} \mathrm{MD}$, Department of Ophthalmology, Otorhinolaringology and Head and Neck Surgery, Hospital das Clínicas of Ribeirão Preto, São Paulo University, Ribeirão Preto (SP), Brazil.

$2 \mathrm{MD}$, Department of Pathology, Hospital das Clínicas of Ribeirão Preto, São Paulo University, Ribeirão Preto (SP), Brazil.

Correspondence address: Patricia Mitiko Santello Akaishi. Hospital das Clínicas - Campus. Av. Bandeirantes, 3.900 - Ribeirão Preto (SP) - CEP 14049-900

E-mail: patriciamitiko@gmail.com

Recebido para publicação em 05.05.2009

Última versão recebida em 30.03.2010

Aprovação em 05.04.2010
}

total retinal detachment overlying a posterior intraocular mass. Topographic and magnetic resonance images revealed that the intraocular mass had no orbital extension. As the findings were compatible with coroidal melanoma, enucleation was advised. After surgery, macroscopic examination disclosed a large $(20 \times 6 \mathrm{~mm})$ justapapilary scleral nodule (Figure 1). Microscopic examination revealed a granuloma with caseation limited to the sclera. Acid-fast bacilli were found in sections with Ziel-Nielsen staining (Figure 2). A systemic work-up did not show any evidence of tuberculosis elsewhere.

\section{DISCUSSION}

It is well known that after the primary pulmonary infection, $M$. tuberculosis bacilli can spread by lymphohematogenous route and remain dormant inside macrophages over long periods of time. During this latency period the balance between the host immune response and the pathogen can be altered any time in life producing clinical disease in almost every organ of the body (extrapulmonary TB) ${ }^{(2)}$. Granuloma formation is the hallmark of TB. Its function is to contain M. tuberculosis at the site of infection and to prevent dissemination of the pathogen. Morphologically granulomas are formed by a central necrotic core surrounded by layers of macrophages, epithelioid cells, multinucleated Langhans giant cells and lymphocytes ${ }^{(4)}$. The most common clinical presentation of intraocu$\operatorname{lar}$ TB is uveitis ${ }^{(3)}$. In the majority of cases the diagnostic is presumed due to the difficult in microbiological examination ${ }^{(5)}$. Scleral involvement is extremely uncommon. Only a few cases of anterior scleritis have been reported ${ }^{(6)}$. In the eye large granulomas are seen only in the choroid as solitary masses mimicking a tumor ${ }^{(3)}$. We believe that our case is the first well documented large posterior TB scleral granuloma. Different populations of T cells control the granuloma organization ${ }^{(4)}$ and certainly the chronic use of immunosuppressant agents weakened the immune system of our patient provoking the development of such large lesion. The sclera around the optic nerve is perforated by branches of the short ciliary arteries. The rich vascular plexus of this region explains the location of this unique granuloma. 

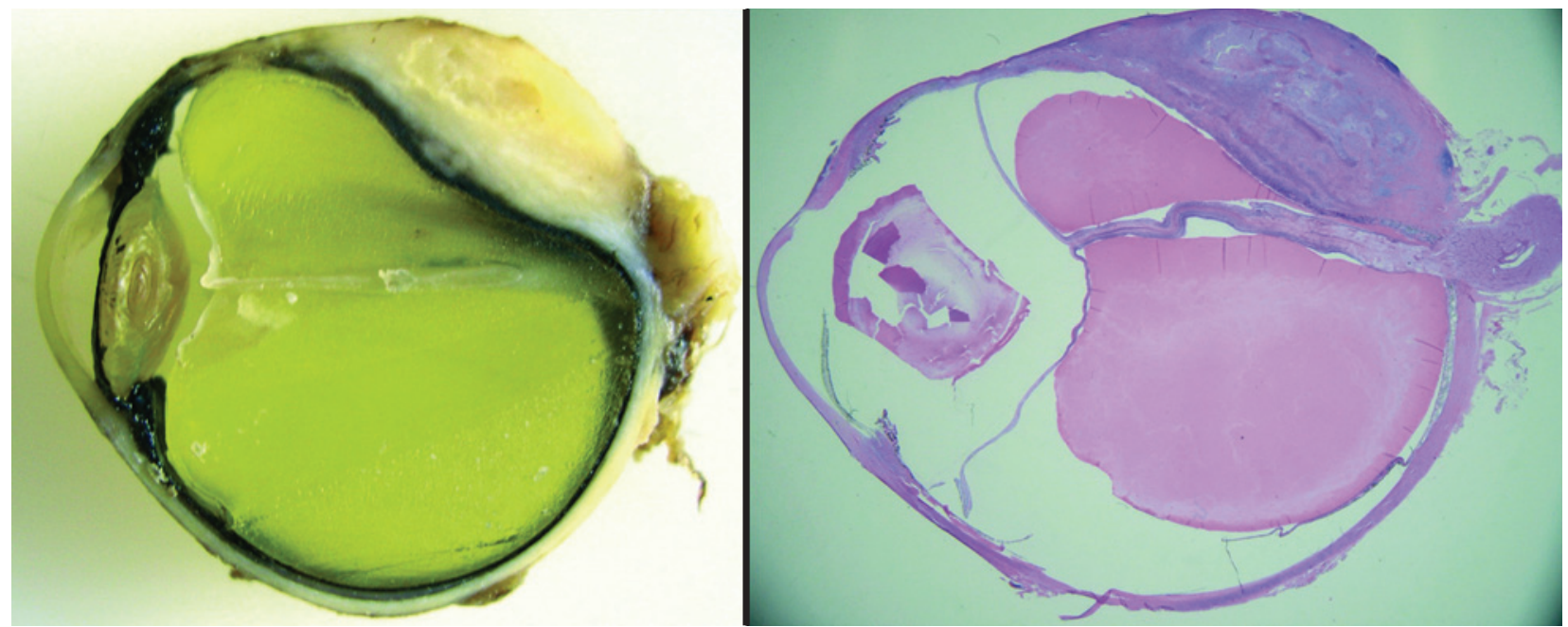

Figure 1. Left: Nodular, yellowish scleral lesion, posterior to the equator causing deformity of the eyeball and total retinal detachment. Right:The lesion is composed of several granulomas with central caseous necrosis (H\&E, panoramic).

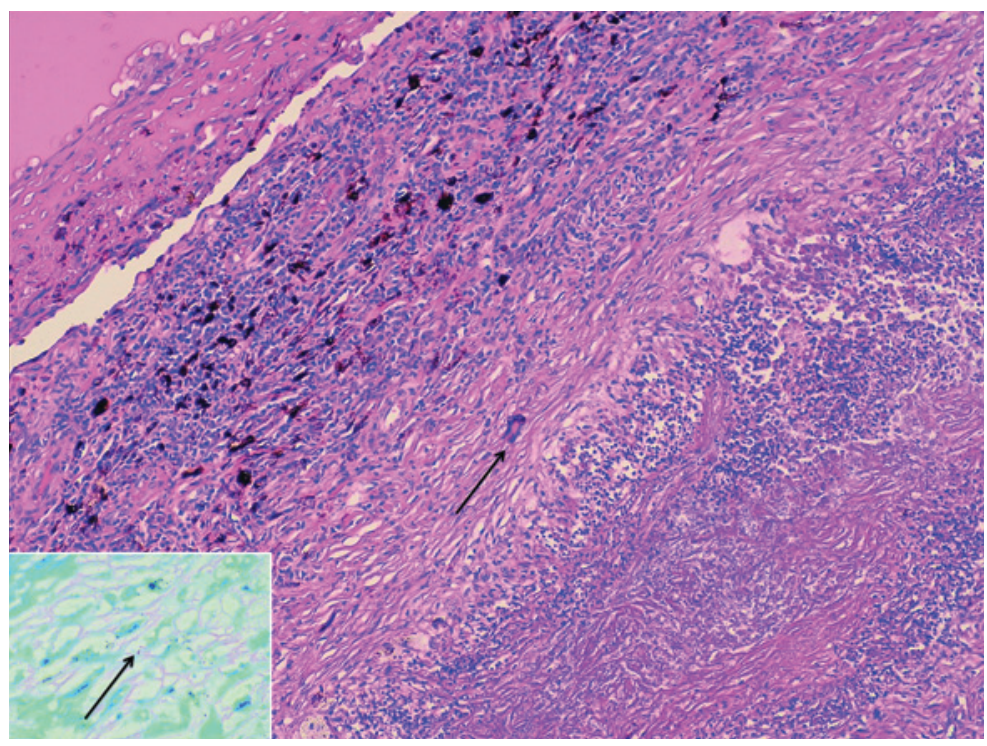

Figure 2. Granulomatous reaction with central necrosis affecting the sclera. The arrow points to a multinucleated giant cell of the Langhans type at the periphery of the granuloma (H\&E, 100x). Inset: Special stain demonstrated acid fast bacilli (arrow) among the inflammatory infiltrate (ZiehlNeelsen, immersion).

\section{REFERENCES}

1. World Health Organization. Global tuberculosis control: surveillance, planning, financing [Internet]. Geneve:WHO; 2007. WHO/HTM/TB/2007.376). [cited 2010 Jul 27]. Available from: http:/www.who.int/tb/publications/global_report/2007/pdf/full.pdf

2. Fitzgerald D, Haas DW. Mycobacterium tuberculosis. In: Mandel GL, Bennett JE, Dolin R, editors. Mandell, Douglas, and Bennett's principles and practice of infectious disease. Philadel phia: Elsevier Churchill Livingstone; 2005. p.2852-86.
3. Gupta V, Gupta A, Rao NA. Intraocular tuberculosis - an update. Surv Ophthalmol. 2007; 5(6)2:561-87.

4. Ulrichs T, Kaufmann $\mathrm{SH}$. New insights into the function of granulomas in human tuberculosis. J Pathol. 2006;208(2):261-9.

5. Almeida SR, Finamor LP, Muccioli C. [Ocular manifestation in patients with tuberculosis]. Arq Bras Oftalmol. 2006;69(2):177-9. Portuquese.

6. Saini JS, Sharma A, Pillai P. Scleral tuberculosis. Trop Geogr Med. 1988;40(4):350-2. 